\title{
Degradation of Wetlands and Livelihood Dependence on Lake Abaya-Chamo Wetland, Southern Ethiopia.
}

Tariku Zekarias ( $\nabla$ tarezekarias@gmail.com )

Arba Minch University https://orcid.org/0000-0003-4468-6924

Vanum Govindu

Arba Minch University

Yechale Kebede

Arba Minch University

Abren Gelaw

Arba Minch University

\section{Research}

Keywords: wetland degradation, livelihood services, overuse of resources, Abaya-Chamo lakes

Posted Date: February 8th, 2021

DOI: https://doi.org/10.21203/rs.3.rs-165097/v1

License: (a) (i) This work is licensed under a Creative Commons Attribution 4.0 International License. Read Full License 


\section{Abstract}

Abaya-Chamo and other wetlands of Ethiopia provide multiple ecosystem services, they are extremely affected by various anthropogenic factors. The unsustainable use of wetlands stems from the negligence of the users about the wetland degradation and the limited policy attention by decision-makers. This study was aimed at analyzing the livelihood benefits of Abaya-chamo lake-wetland and the driving forces of its degradation. Data were gathered using questionnaire survey of 384 households (selected via systematic random sampling), focus group discussion, interview and field observation. Percent, regression, etc., were used for data analysis. It was found that Abaya-chamo lake-wetland offers fish, timber, firewood, fodder, irrigation water, farmland, rainfall, recreation, tourism, aesthetic, carbon sink, air quality and climate regulation, etc., services to local people. Farm expansion, sedimentation, irrigation, invasive plants (e.g. emboch), open access and overuse of resources, lack of legal framework and rapid population growth were the main causes of the wetland degradation. Applying the lakes' salty-water for irrigation is expected to lead to chemical land degradation in the next few decades. The invasive embochplant results in dwindling aquatic resources (e.g. fish), loss of economic and tour benefits, and change in local climate thereby depleting the lake water, and the dissolved $\mathrm{O}_{2}$ and $\mathrm{CO}_{2}$ storage capacity of the lakewetland rapidly. The lakes' salty-water based irrigation is expected to result in chemical land degradation to the extent of abandoning crop farming in the next few decades unless some actions are taken. Thus, the government should formulate clear policy and legal framework about sustainable management of wetland resources.

\section{Background}

Wetlands are among the planet most biologically productive ecosystems and rich in diversity of species. Human activities pose threats on the well-being of wetlands, leading to either their loss or degradation (Bjerstedt, 2011). Wetlands, constituting only $1.5 \%$ of the area of earth, renders about two-fifth (40\%) of the ecosystem services globally (Zedler and Kercher, 2005). A wetland (inland) ecosystem provides services with an estimated value of US\$44,000 per/ha/year (TEEB, 2013; Clarkson et al., 2014); these services include provisions (fish, fodder, timber, medicines and oil, etc.), support farming, carbon sink, maintaining air and water quality and supply, and the hydrological and biogeochemical cycles, regulating climate, stabilizing shorelines, curbing flood hazard, sustaining flora and fauna, treating liquid waste, cultural and recreational uses, etc., (Dise, 2009; Egoh et al., 2012; Clarkson et al., 2014).

Wetlands undergone loss or degradation despite the multiple services they provide to people. 'Wetland loss' is defined as the transformation of wetlands to non-wetlands due to the impact of natural and anthropogenic factors; whereas 'wetland degradation' is human actions-induced "impairment of wetland functions" which delivers goods and services (Moser et al., 1996). Wetland loss or degradation occurs due to natural and human factors. These factors lead to depletion of ecological values of services derived from wetlands, and the loss of livelihood sources of people nearby wetlands. Livelihood is described as the combination of social, human, physical, economic, and natural capitals (Scoones, 2009). The use of wetlands for crop farming has increased in recent decades (Dixon and Wood, 2003), 
which is underlain by population growth, climate change, globalization (Van-Asselen et al., 2013), and changes in policy and governance structures (Davidson, 2014).

Several studies stress on the role of ecosystems (natural capital) to extend access to the other capitals, resulting in poverty reduction and resilience to global climate change impact (Akwetaireho and Getzner, 2010; Fisher et al., 2014). Recent global ecological crises, such as climate change and ecosystem degradation, severely affect the livelihoods of ecosystem dependent communities in sequential order, such as reduced agricultural production, squeezed livelihood options, increased poverty, and eroded adaptive capacities across various scales (Reed et al., 2013b). Even if livelihood diversification is commonly suggested as a viable option to those crises and uncertainties, it is also essential to assess the livelihood vulnerability within the broader perspective of ecosystem-based adaptation and sustainable livelihood planning (Gautam and Andersen, 2016). One important pre-requisite in ecosystembased livelihood development is to have a qualitative and quantitative understanding of the relationship of the livelihood system and ecosystem in a given social-ecological system (Gautam and Andersen, 2016).

Wetland loss/degradation has been associated with rapid population growth, overexploitation and unsustainable management practices, which adversely affect the livelihoods of local communities (Trinh et. al., 2003). Wetlands are often perceived to have little or no value compared to other potential uses of land that enable to produce immediate economic benefits. But wetland ecosystems have been severely degraded since some recent decades-past due to its overwhelming exploitation (Davidson, 2014). The protection of the wetlands reserves numerous valuable goods and services to the local communities and also, to the people outside the wetland areas (Egoh et al., 2012).

The deteriorating state of wetlands and consequent threats on sustainability of livelihoods remains a key concern to many governments, especially in developing countries. Increasing population and rural poverty have already damaged wetland ecosystems (Rahman and Islam, 2005). Wetland ecosystems are important from conservation and sustainable management viewpoints as they are rich in diversity of flora and fauna (CBD, 2015). Tangible and intangible diverse services and products of wetland functions such as fodder, fishes, fuel-wood, non-timber forest products, ecotourism and flood control have been sources of income and livelihood means for humans. However, population growth and associated factors have depleted these resources and reduced the flow rates of the ecosystem services. The loss of wetland ecosystem services damages the health and well-being of individuals and communities and diminishes their development prospects (MEA, 2005; Clarkson et al., 2014).

The sustainable use of wetlands and associated ecosystems is influenced by diverse interactive factors such as rapid population growth, expansion of farming, use of chemical farm inputs, irrigation, invasive or alien species, changes in the way of life of people, infrastructure expansion, urbanization, overgrazing, open access and overuse of resources, drought, climate change, policy change, lack of sound policy, etc., (Egoh et al., 2012; Heathwaite et al., 2012; Van-Asselen et al., 2013; Davidson, 2014; CBD, 2015). Diverting water flow from tributaries, runoff from croplands and urban areas, withdrawal of water from lakes, high 
evaporation, frequent siltation, pollution, etc., are the specific factors which threatens the biodiversity and services of wetlands (Ayenew, 2004). But all these factors could not be equally significant in degrading the functions and services of wetlands, and the lives of people whose livelihoods are linked to the wetlands everywhere (MEA, 2005b).

The interlinkage between wetland ecosystems and livelihoods is hardly appreciated by policy makers despite the paramount importance of the diverse services wetland ecosystems render to people and nature (MEA, 2005a; CBD, 2015). The formulation of sound policy and management strategies on wetlands requires holistic understanding on how wetland ecosystem functions are affected by natural and anthropogenic factors, and how degradation of wetland resources influence livelihoods (Boyd, 2012; CBD, 2015). It is also vital to understand how people make decisions on resource exploitation and how sociocultural and policy factors affect those decisions (MEA, 2005b; Boyd, 2012).

Wetland ecosystems of Ethiopia have experienced severe degradation due to anthropological factors. The wetland ecosystems have been threatened due to shortage and expansion of cropland, overgrazing and shrinkage of grazing-land, open access and overuse of ecosystem services, etc., underlain by rapid population growth. As a consequence of changes in land use land cover, sloping areas faced raising erosion and depletion of nutrients required for vegetative growth. Increased erosion and the resulting sedimentation elsewhere can have a major impact on the lake hydrology (Feoli and Zerihun, 2000). Soil degradation, dwindling landholding-size plus its fragmentation, and increasing rainfall variability-induced decline agricultural productivity in the highlands of Ethiopia has resulted in the shift of farmers from upland to wetland-based crop production (Symeonakis and Drake, 2010; Sakané et al., 2011). Increasing food production from wetlands needs to be reconciled with protection of environmental resources. Striking the balance between maximizing benefits of wetland agriculture while minimizing adverse impacts on other ecosystem services has been described as the main dilemma of current policies on and management of wetlands (McCartney et al., 2010).

Wetlands of Abaya-Chamo basin, being within the Ethiopian Rift-valley, have been providing diverse goods and services to the people locally and away from the wetlands. However, the wetland resources have been severely threatened by the impact of largely anthropogenic factors. In fact, studies about land use/cover dynamics, ecosystem services-values, food security conditions, biophysical-geological changes of the lake-water, etc., have been conducted within and around Abaya-Chamo wetlands, Southern Ethiopia (Gelaw, 2007; Kebede, 2012; Uncha, 2014; Assefa and Bork, 2016; Teffera et al., 2017; Gelaw, 2019). But none of these studies has attempted to assess the current conditions and benefits of Abaya-Chamo lake-wetland, and the extent and driving forces of degradation of the wetland ecosystem. Assessing the services derived from the lake-wetland, the sphere of its degradation, and the direct and root causes of degradation is useful to formulate sound policy and sustainable management options about the lake-wetland resources (Boyd, 2012; CBD, 2015). This study was targeted to (1) asses the goods and services derived from lake Abaya-Chamo lake-wetland by the local people; (2) analyze the impacts of selected household and livelihood-related variables on the wetland ecosystem (degradation); and, (3) examine the driving forces of degradation of the lake-wetland resources. 


\section{Materials And Methods \\ Description of Study Area}

Abaya-Chamo wetland is found in Southern Rift-Valley of Ethiopia. Abaya lake is located in $5^{\circ} 3^{\prime} 19^{\prime \prime} \mathrm{N}-6^{\circ}$ $45^{\prime} 11^{\prime \prime} \mathrm{N}$ latitude and $37^{\circ} 18^{\prime} 55^{\prime \prime} \mathrm{E}-38^{\circ} 75^{\prime} 5^{\prime \prime} \mathrm{E}$ longitude; and, Chamo lake is located in $5^{\circ} 43^{\prime} \mathrm{N}-5^{\circ} 59^{\prime} \mathrm{N}$ latitude and $37^{\circ} 32^{\prime} \mathrm{E}-37^{\circ} 45^{\prime} \mathrm{E}$ longitude (EMA, 1988). In Fig. 2.1, the light-blue shaded part is Abaya lake and the deep-blue one is Chamo lake. Abaya and Chamo have been interconnected in the past with water flowing from Abaya into Chamo lake via Kulfo river, but the lakes were disconnected from 1980 until 2013 (Teffera et al., 2017).

Mean annual temperature of Abaya-Chamo basin/wetland, based on data of 1987-2018, was about 24 ${ }^{0} \mathrm{C}$; and, the mean monthly temperature of the area is the highest in march $\left(26{ }^{\circ} \mathrm{C}\right)$ and the lowest in July $\left(23^{\circ} \mathrm{C}\right)$, November $\left(23.1^{\circ} \mathrm{C}\right)$ and December $\left(23.1^{\circ} \mathrm{C}\right)(\mathrm{NMA}, 2019)$. The wetland receives a somewhat low rainfall amount where the mean total annual (1982-2018) was $870.9 \mathrm{~mm}$. The study area has two rainfall seasons: that is, Spring (March, April and May) with total rainfall of $362.9 \mathrm{~mm}$ is the main rainy season. In Spring, rainfall, averaged for 37 years (1982-2018), is the highest in April (153.7 mm). Autumn (September, October and November) with total rainfall amount of $265.6 \mathrm{~mm}$ is the second rainy season where it peaks in October (115 mm) (NMA, 2019).

The present geomorphic feature of Lake Abaya-Chamo basin/wetland, being within the Ethiopian Rift Valley, is the combined effect of natural processes such as divergent tectonic movement (between the African Plate-westward and the Somalia Plate-eastward), faulting, volcanism, and alluvial and lacustrine deposition. The faulting/rifting, volcanic and deposition processes resulted in the formation of graben (depression), volcanic hills (islands) and shallowness of the lakes' (Abaya-Chamo) depth, respectively. The western edges of Abaya and Chamo lakes are covered by alluvial and lacustrine deposits, and swamps. Rivers like Bilate, Gelana, Gidabo and Hare flow into Abaya lake, and Kulfo and Sille streams drain into Chamo lake. Fluvisols, being the result of alluvial and lacustrine deposits, dominate AbayaChamo wetland and the adjacent low-lying areas (Engidawork, 2001; Gelaw, 2007). The fertile luvisols, having good agricultural potential, covered the eastern side of Chamo lake. The soils are intensively used for agricultural production (Kebede, 2012; Gelaw, 2019).

The extensive deforestation within and adjacent to lake Abaya-Chamo wetland was for the expansion of croplands and settlement. Extensive area to the west of lake Abaya-Chamo basin was cleared in the 1960s and 1970s for establishment of large-scale mechanized farms (Gelaw, 2019). Agroforestry is the main activity in the alluvial plain of the western shores of the lakes, where it is practiced using rain-fed and irrigation. Fruits (e.g. banana, mango, avocado, papaya, tomato, etc.)), cereals (e.g. maize), vegetables (e.g. cabbage, pepper, etc.), tuber and root crops (casava, onion, carrot, etc.) and cotton are cultivated on the fertile soils adjacent to the wetland (Gelaw, 2007; Gelaw, 2019). Wetlands, forest, woodland and bush-lands have changed to settlement and cropland (Kebede, 2012). 
Total population of Arba-Minch Zuria Woreda based on 2015 survey, was 165,680; where males were $49.96 \%$ (82,774); females were $50.04 \%(82,906)$ (CSA, 2015). The population living in the area adjacent to lake Abaya-Chamo wetlands was about 73,231 (44.2\% of the total population of Arba-Minch Zuria Woreda), where males were $50.5 \%(36,982)$ and females were $49.5 \%(36,249)(C S A, 2015)$.

\section{Research Methods}

\section{Data Sources and Methods of Collection}

Both primary and secondary data were used for the study. Primary data about human activities, ecosystem goods and services, livelihood conditions and challenges on Abaya-Chamo wetland were collected through questionnaire, Focus Group Discussions (FGD), Key Informant Interview (KII) and field observation (Creswell, 2009). Questionnaire, having close-ended and open-ended questions, was used to gather data via household survey. FGD and KII were also used to collect data about change drivers, benefits and threats on Abaya-Chamo wetland.

Secondary data were obtained from books, journals/articles, internet sources, research reports, and statistical reports of the Ministry of Agriculture, Environmental Protection Authority, Department of Natural Resources, Fishery Cooperatives, etc.

\section{Sampling Techniques}

Initially, six (6) sample villages (Kebeles) were identified using purposive sampling; that is, villages adjacent to Abaya-Chamo lake-wetland were selected. Sample size of households was determined on account of inferences (at least at $95 \%$ ) about the study population based on analysis of data acquired from sample households (Gujarati, 2004; Creswell, 2009). That is, the sample size was determined using the following procedure (Cochran, 1977):

$$
\mathrm{n}=\frac{\mathrm{Z}^{2} \mathrm{PQ}}{\mathrm{e} 2}
$$

Where: ' $n$ ' is the desired sample size, ' $Z$ ' is the standard normal deviation at the desired confidence level of $95 \%$ (1.96), ' $p$ ' is the proportion of the target population that is estimated to affect or to be affected by the wetland (i.e. $50 \%$ or 0.5$), ' q$ ' $=1-p(1-0.5=0.5)$ and $e=$ is the standard error $(0.05)$. 
Table 2.1

Total House-Hold Heads ( $\mathrm{HHH}$ ) and Sample Size of $\mathrm{HHH}$

\begin{tabular}{|lllllll|}
\hline N0 & Kebele/Village Name & Total HHH & \multicolumn{2}{l}{ Sample HHH } & & \\
\cline { 5 - 7 } & & & Males & Females & Total & Percent (\%) \\
\hline 1 & Chano Mille & 255 & 48 & 19 & 67 & 17.5 \\
\hline 2 & Lante & 280 & 64 & 9 & 73 & 19.0 \\
\hline 3 & Ganta kanchama & 265 & 63 & 7 & 70 & 18.2 \\
\hline 4 & Elgo & 210 & 50 & 5 & 55 & 14.3 \\
\hline 5 & Shara & 295 & 71 & 6 & 77 & 20.1 \\
\hline 6 & Omo Lante & 160 & 38 & 4 & 42 & 10.9 \\
\hline & Total & $\mathbf{1 , 4 6 5}$ & $\mathbf{3 3 4}$ & $\mathbf{5 0}$ & $\mathbf{3 8 4}$ & 100.0 \\
\hline Source: Office of Arba-Minch Zuria Woreda, 2019 & & & & \\
\hline
\end{tabular}

Total sample households became 384; of who, $87 \%$ were male-headed and $13 \%$ were female-headed. Sample size based on Kebele and gender class was determined via proportionate sampling (Table 2.1). Finally, the target sample household heads were identified using systematic random sampling, that is, starting randomly every $\mathrm{k}^{\text {th }}$ (4th) household head was taken until all the 384 were acquired.

Four groups (each group consisted of 8-10 individuals) were used for FGD. Members of the FGD were selected purposively; and, each group consisted of elders, development agents, women, youth, etc. Eight (8) key informants (4 members of Fishery Cooperatives, 2 experts in Natural Resource Protection and 2 local elders) were selected purposively upon their experience about lake Abaya-Chamo wetland.

\section{Data Analysis}

Date collected using questionnaire were entered to SPSS (version 20.0). Normality test was conducted using Kolmogorov-Sminov test to decide whether a parametric or non-parametric test should be used. Spearman's rank correlation was used to analyze the relationship between dependent variable (wetland degradation) and other variables such as household size, age, period of wetland use, farm distance from the wetlands, etc. Percent, mean and Tropical Livestock Unit (TLU) were used for analysis. Multiple linear (binary logistic) regression model was applied to evaluate the impact of household-related independent variables on the dependent variable, 'wetland ecosystem' (about which data from respondents were gathered using binary response-options); that is, the linear regression model used is (Gujarati, 2004):

$Y=a+\beta_{1} X_{1}+\beta_{2} X_{2}+\beta_{3} X_{3}+\beta_{4} X_{4}+\beta_{5} X_{5}+\beta_{6} X_{6}+\beta_{7} X_{7}+\beta_{8} X_{8}+\beta_{9} X_{9}+\beta_{10} X_{10}+\beta_{11} X_{11}+\beta_{12} X_{12}+\mu$ 
Where: $Y=$ dependent variable (degradation/loss of wetlands), $a=$ constant, $X_{1}-X_{12}$ are independent variables; that is, $X_{1}=$ total income, and, $X_{2}$ tropical livestock unit (TLU), $X_{3}=$ farmland size, $X_{4}=$ distance of farm land, $X_{5}=$ household size, $X_{6}=$ land size, $X_{7}=$ age of the respondents, $X_{8}=$ farming experience, $X_{9}$ $=$ off farm activities, $X_{10}=$ access to credits, $X_{11}=$ gender of the respondents and $X_{12}=$ marital status and $\mu=$ error term (residual). Values $\beta_{1}-\beta_{12}$ are the parameters estimated (i.e. the respective coefficients of the independent variables $X_{1}-X_{12}$.

\section{Results And Discussion}

\section{Livelihood Benefits of Lake Abaya-Chamo Wetland}

Degradation or loss of Abaya-Chamo wetlands emanates largely from crop-farming induced run-on, sedimentation and eutrophication problems resulting from the surrounding uplands, open-access and overuse of the wetland resources due to peoples' dependence (partly or fully) on the wetlands for their livelihood needs, etc. The main livelihood benefits (goods and services) obtained from Abaya-Chamo wetland ecosystem were organized upon evidences acquired from the perception and experiences of households, and through field observation about the wetland ecosystem (Table 3.1).

Table 3.1

Goods and Services Obtained from Lake Abaya-Chamo Wetland Ecosystem

\begin{tabular}{|llll|}
\hline N0 & Benefits/Services & N0 of HH & P (\%) \\
\hline 1 & Fish for food or cash & 321 & 83.6 \\
\hline 2 & Water for livestock and domestic use & 227 & 59.1 \\
\hline 3 & Timber (for making boats and benches) and firewood & 128 & 33.3 \\
\hline 4 & Grazing and fodder/grass for livestock or cash & 312 & 81.3 \\
\hline 5 & Irrigation for cash-crop farming (e.g. fruits, vegetables, tubers/roots) & 296 & 77.1 \\
\hline 6 & Land (soil) for primary (e.g. crop) production & 107 & 27.9 \\
\hline 7 & Natural (e.g. hippos) and managed (e.g. crocodile) home of animals & 198 & 51.6 \\
\hline 8 & Recreation (e.g. swimming) and ceremonial (e.g. weddings, parties) & 184 & 47.9 \\
\hline 9 & Tourism and aesthetic value & 286 & 74.5 \\
\hline 10 & Regulation of local climate (e.g. temperature, rainfall, wind, etc.) & 277 & 72.1 \\
\hline & Total & 384 & 100.0 \\
\hline Source: own field survey, 2019/20 (Note: results in Table 3.1 are based on multiple response-options) \\
\hline
\end{tabular}


As it is displayed in Table 3.1, so many people harvest fish for food or cash (83.6 \%) from Abaya and Chamo lakes, use the wetland for grazing and generating fodder/grass for livestock or cash (81.3\%) usually during dry conditions, exploit the lakes' water for livestock and domestic use (59.1\%), and generate timber from woodlands and patches of forests (e.g. Sokie tree) of the wetlands for making traditional boats (used for fishing by fishermen) and firewood (33.3\%). The mean annual fish catch (2013-2019) from Abaya and Chamo lakes by legal fishermen is too small (31,791.2 quintal) from the existing high fish yield potential; of this, 73.3 \% (23,301.5 quintal) is from Chamo lake and $26.7 \%$ (9,918.2 quintal) is a catch by legal fishermen in the west-south-west coast of Abaya lake (Table 3.3, Appendix). Even if Abaya lake has high supply of fish (e.g. tilapia, Nile-perch, etc.), its share (\%) of annual fish catch is small; this is a result of the siltation induced high turbidity of the lake-water throughout the year (Teffera et al., 2017), which makes fishing risky due to crocodile attack.

The Abaya-Chamo lake-wetland also provide supportive services to the local people and people away from the wetland such as irrigation water $(77.1 \%$ ) and fertile land/soil for primary (crop) production (27.9 \%) (Table 3.1); meaning, the lakes' water and the neutral to alkaline land (soil) in the western part of Abaya-Chamo wetland (Gelaw, 2007) is being used for the production of fruits (e.g. banana, mango, tomato, pepper, etc.), vegetables (e.g. cabbage, salad, etc.), tuber and root crops (e.g. onion, carrot), tobacco, etc., using water pump motor-based irrigation by farmers and small scale investors. The lakewetland offers a supportive service since it has natural (e.g. hippos, crocs, birds like pelican, etc.)) and managed (known as 'Arba-Minch Crocodile Ranch' at the southwestern tip of Abaya lake) habitats (51.6 \%) (Table 3.1).

The Abaya-Chamo wetland also provides cultural services such as 'tourism and aesthetic values' (74.5 $\%$ ), and 'recreational (e.g. swimming) and ceremonial (e.g. weddings, parties) services' (47.9\%) (Table 3.1). The local people (especially the youth) frequently swim in Abaya and Chamo lakes, and the Arba-Minch (Forty-Springs) so as to cool their bodies and refresh their minds where the weather is too hot, the mean annual temperature is $24{ }^{\circ} \mathrm{C}$ and the daily maximum temperature during September - April exceeds $30^{\circ} \mathrm{C}$ (NMA, 2019). The coasts of the two lakes, and the Arba-Minch (Forty-Springs) frequently get crowded with participants of wedding ceremonies (during wedding periods in Ethiopia) and parties or special occasions in weekends. The Abaya-Chamo lake wetland is among some of the most preferred tourism destinations for domestic and foreign tourists in the areas surrounding the wetland and ArbaMinch town in Ethiopia. This is so because, it has various tourist attractions such as the numerous small islands, hippos, crocodiles, various species of birds, the 'Arba-Minch Crocodile Ranch,' the 'Arba-Minch' (which refers to the 'Forty-Springs' situated between Abaya and Chamo lakes, and from which name of Arba-Minch Town was coined and the town's potable water supply service is generated) and a beach locally known as Azo Gebeya ("crocodile market" - located in northeastern part of Chamo lake is not a site where crocs are exchanged, rather, where crowds of crocodiles are observed and visited). All these are valuable tourism-induced sources of earning to the government (via tourism and the export of skins of crocodiles), local retailers and tour-guides. Moreover, the two lakes and the associated swamps of Abaya- 
Chamo wetland, being surrounded by the western and eastern escarpments of the Ethiopian Rift-Valley, have maximized the natural beauty of the environment around the wetland.

Abaya-Chamo wetland is valuable in regulation of the local climate (72.1\%) (Table 3.1); the wetland, being located in semi-arid tropical environment, is useful in moderating local climate; that is, where the lakes have cooling effect during daytime in months of hot weather conditions due to sea breeze (i.e., a cool air blowing from Abaya and Chamo lakes to the surrounding landmass during daytime) resulting from the air pressure differences between land and sea (the lakes) locally. The lake-wetland also regulates air quality by storing huge amount of dissolved $\mathrm{CO}_{2}$ within its lakes and the surrounding swamps; this, in turn, implies that the study wetland controls the level of land surface temperature by reducing the amount of greenhouse gas emission to the atmosphere (Egoh et al., 2012; Clarkson et al., 2014). The Abaya-Chamo lake-wetland is also a key source of rainfall to the local people (farmers) as the lakes are conducive surfaces for evaporation to take-place, meaning, it facilitates the hydrological cycle, which is a supportive service for crop farming (MEA, 2005). Since the wetland is located in the semi-arid Ethiopian Rift-Valley depression, its rainfall supply is adversely influenced by 'rain-shadow location' on the leeward sides of the western escarpment (for moist winds from west) and the eastern escarpment (for moist winds from east) of the Rift-Valley. It is because of such topographic barriers that the AbayaChamo lake-wetland receives a mean total annual rainfall of about $870.9 \mathrm{~mm}$ only (NMA, 2019). Generally, the lake-wetland and its surrounding areas (western coasts) usually receive better rainfall amount when rainfall commences from Abaya and Chamo lakes, and the associated swamps.

\section{Driving Forces (Causes) of the Degradation/Loss of Abaya- Chamo Wetland}

The degradation/loss of Abaya-Chamo lake-wetland is the combined effect of various anthropogenic factors, which have originated from the heavy dependence of the local community on the goods and services of the wetland ecosystem. Results about the driving forces of degradation of Abaya-Chamo wetland are illustrated in Fig. 3.1.

The degradation of Abaya-Chamo wetland and its benefits has been driven by crop farming expansion $(60.2 \%)$, use of the lakes' water for irrigation (65.6\%), sedimentation (44\%), overgrazing or frequent use of the wetland for livestock grazing (59.6\%), invasion of the two lakes by exotic plant species (e.g. emboch) $(50.8 \%)$ and overfishing ( $40.7 \%)$ underlain by rapid population growth (53.1\%), open access $(69.3 \%)$ to and low protection (61.7\%) of the wetland resources (Fig. 3.1). Farm expansion towards the wetland and marginal areas was induced by shortage of farmland (Assefa and Bork, 2016) and overgrazing was due to shrinkage of grazing-land in the areas adjacent to the study site (Kebede, 2012; Assefa and Bork, 2016); that is why (from results of the regression analysis) landholding size (with beta coefficient of -0.206 and sig value of 0.003 ) and livestock population/TLU (with beta coefficient of -0.119 and sig value of 0.001) were found to have significant negative impacts on Abaya-Chamo 'wetland resources' at $99 \%$ confidence level (see Table 3.2 below); i.e. where these factors contributed to the degradation of the wetland resources (Bakala et al., 2019). In fact, household size of the rural residents 
(with a coefficient of -0.014 and sig value of 0.000 ) also showed a significant adverse effect on the 'wetland ecosystem' (Table 3.2); that is, the tendency to generate more services from the lake-wetland and associated resources, and the likelihood of degrading the wetland is higher for households with smaller family size; this could be due to involvement of more members of $\mathrm{HH}$ with larger family size in other offfarm businesses (other than deriving products from the wetland) or their better success in agriculture production, etc. Informants and discussants of the FGD also confirmed that the expansion of farming (to the extent the wetland lost its buffer zone), intensive grazing and the frequent harvest of fish (by legal and illegal fishermen) have resulted in the degradation of the Abaya-Chamo wetland.

The irrigation, upon the tributaries of Abaya-Chamo wetland, is not a critical threat on the sustainability of the wetland. Irrigation, rather, has become real challenge on the sustainability of the wetland and its associated resources roughly since the onset of the last decade (2011-2020) - a turning point for the beginning of extensive use of the salty-water of Abaya and Chamo lakes for irrigation-based cash crop production in the western coast of the wetland and the adjacent plains by the local farmers and small scale investors in agriculture. It is carried out (as it was observed on-site) using largely motors that pump the lake-water through plastic pipes to the cultivated field where cash crops such as banana, papaya, onion, tomato, pepper, cabbage, tobacco, spinach, lettuce, etc., are grown.

Factors such as farm expansion, irrigation, sedimentation and overgrazing together with the depletion of vegetation cover in the uplands (escarpments of the Rift-Valley) have contributed to the degradation of Abaya-Chamo lake-wetland in at least five ways: first, expansion of farming has resulted in the removal of natural vegetation (e.g. woodland, grassland, forest and bush) nearby the coasts of the lakes (which was used as a buffer zone of the lakes) and loss of its biodiversity. Second, the destruction of the natural vegetation adjacent to the lakes aggravated the magnitude of sedimentation and the entrance of chemical pollutants (e.g. nitrate, phosphate, etc.,) in to Abaya and Chamo lakes. Third, applying the lakes' salty-water for crop farming in coastal lands where evapotranspiration is so high results in an increase in alkalinity (sodic toxicity) of the soil and chemical degradation of land nearby the lakes. Fourth, the chemical fertilizers and pesticides used for cash-crop farming by farmers and investors (plus the fertilizer used in the surrounding highlands) is aggravating pollution of the lakes due to siltation by runoff from uplands. Fifth, actions pointed out in \# 1-4 above have resulted in eutrophication, which is a dense growth of a unique/exotic plant, locally known as 'emboch', in Abaya and Chamo lakes due to raising concentration of nutrients (e.g. nitrate) in the lakes. This in turn deteriorates the biodiversity (fish, plants and animals) and sustenance of the wetland ecology since the thick-leafed and deep green emboch-plant consumes water at an alarming rate - where the resultants of the invasive plant become shrinkage of the lakes, dwindling supply of dissolved $\mathrm{O}_{2}$, decline storage of $\mathrm{CO}_{2}$, loss of aquatic biotas, climate change and disruption of the overall ecological balance of the area around the lake-wetland (Zhang et al., 2007; Erwin, 2009; Swinton et al., 2007; Davidson, 2014; CBD, 2015).

Key informants and participants of the FGD stressed that the depth of Abaya and Chamo lakes is progressively becoming shallow due to increasing sedimentation in the floor of the lakes, which is loaded by runoff (from uplands) and tributaries of the lakes. In fact, anyone who has been observing the lakes 
since five to ten years-ago may think that the volume of the lakes is increasing overtime; this is so because, the lakes have shown certain extent of lateral spread since some years past. The increasing lateral extent of the lakes, rather, is the result of displacement of water of the lakes in response to the increasing siltation in the lakes. The siltation induced lateral spread of the lakes, again, accelerates the evaporation rate of the lakes, the magnitude of water loss and degradation of the lake-wetland.

A key informant (development agent), age 37, stated that the degradation of Abaya-Chamo lake-wetland is exacerbated due to the lack of clear regulations and legal frameworks on the exploitation and protection of resources of the lake-wetland, and the measures to be enforced on those who abuse the wetland resources (e.g. illegal fishermen, farmers who encroach to the wetland, etc.), and limited commitment of concerned bodies in natural resources protection. The rapid population growth, as a root cause of the wetland degradation (Fig. 3.1), is the combined effect of high natural increase locally and high magnitude of in-migration from Gamo-highlands and Wolyta areas due to push-factors at the origin such as population pressure, declined farm-size, severe soil erosion and low yield, and pull-factors such as availability of fertile land, the gradual development of infrastructures, the provision of health services, and the progressive control of malaria and tsetse-fly (a vector of livestock disease) in the lowland/tropical wetland and its surroundings by the government of Ethiopia (Gelaw, 2019).

In addition to 'household size,' 'landholding size' and 'livestock population', variables such as education $(-0.021)$, gender $(-0.050)$ and marital status $(-0.118)$ revealed significant negative impacts on AbayaChamo 'wetland ecosystem' at $99 \%$ confidence level where the sig values of the respective predictors were $0.005,0.003$ and 0.005 (Table 3.2 below). Meaning, the likelihood of generating products from and encroachment to the wetland resources, and the contribution to the degradation of the lake-wetland is higher for less educated (than more educated), male-headed (than female-headed ones) and married households than unmarried (single, divorced and widowed) ones. 
Table 3.2

Beta (B) Coefficients and Collinearity Statistics of Variables of the Logistic Regression Analysis

\begin{tabular}{|c|c|c|c|c|c|c|c|c|c|}
\hline \multirow[t]{2}{*}{ Variables } & \multicolumn{3}{|c|}{ Beta Coefficients } & \multicolumn{2}{|c|}{ Statistics } & \multicolumn{2}{|c|}{$95 \% \mathrm{Cl}$ of $\mathrm{Bo}$} & \multicolumn{2}{|c|}{ Collinearity Stat } \\
\hline & $\begin{array}{l}\text { Unstd. } \\
\text { B }\end{array}$ & $\begin{array}{l}\text { Std. } \\
\text { E }\end{array}$ & Std. B & $t$ & Sig & Lower & Upper & Tolerance & VIF \\
\hline (Constant) & 2.881 & .166 & - & 17.31 & .000 & 2.554 & 3.208 & - & - \\
\hline $\begin{array}{l}\text { Age of the } \mathrm{HH} \\
\text { head }\end{array}$ & .001 & .004 & 0.010 & 0.175 & .000 & -.006 & .008 & .881 & 1.135 \\
\hline $\begin{array}{l}\text { Education } \\
\text { level }\end{array}$ & -.021 & .053 & -0.021 & -0.392 & .005 & -.126 & .084 & .935 & 1.070 \\
\hline $\begin{array}{l}\text { Household } \\
\text { size () }\end{array}$ & -.005 & .018 & -0.014 & 0.259 & .000 & -.039 & .030 & .918 & 1.089 \\
\hline $\begin{array}{l}\text { Gender of the } \\
\text { HH head }\end{array}$ & -.079 & .081 & -0.050 & 0.984 & .003 & -.238 & .079 & .989 & 1.011 \\
\hline Marital status & -.174 & .076 & -0.118 & -2.288 & .005 & -.324 & -.024 & .979 & 1.022 \\
\hline $\begin{array}{l}\text { Annual } \\
\text { income_ETB }\end{array}$ & $\begin{array}{l}2.514- \\
005\end{array}$ & .000 & 0.052 & 0.998 & .319 & .000 & .000 & .952 & 1.050 \\
\hline $\begin{array}{l}\text { Production } \\
\text { trend }\end{array}$ & .275 & .087 & 0.164 & 3.168 & .005 & .105 & .446 & .952 & 1.050 \\
\hline $\begin{array}{l}\text { Landholding } \\
\text { size (ha) }\end{array}$ & -.175 & .059 & -0.206 & 2.959 & .003 & -.292 & -.059 & .484 & 2.066 \\
\hline $\begin{array}{l}\text { Income from } \\
\text { wetland }\end{array}$ & 2.140 & .000 & 0.044 & 0.784 & .005 & .000 & .000 & .740 & 1.351 \\
\hline $\begin{array}{l}\text { Livestock size } \\
\text { (TLU) }\end{array}$ & -.017 & .010 & -0.119 & -1.714 & .001 & -.038 & .003 & .490 & 2.042 \\
\hline Credit & -.075 & .080 & -0.052 & -0.941 & .347 & -.232 & .082 & .769 & 1.301 \\
\hline $\begin{array}{l}\text { Off-farm } \\
\text { income_ETB }\end{array}$ & $\begin{array}{l}1.14 \mathrm{E}- \\
005\end{array}$ & .000 & 0.104 & 1.670 & .096 & .000 & .000 & .609 & 1.641 \\
\hline
\end{tabular}

On the contrary, predictors such as age of the household head (0.010), crop production trend (0.164) and income from the wetland (0.044) revealed significant positive impacts on Abaya-Chamo 'wetland ecosystem/resources' where the sig values of these predictors were $0.000,0.005$ and 0.005 , respectively (Table 3.2). The impact of other household related variables on the 'lake-wetland ecosystem' was not statistically significant (see Table 3.2). 


\section{Conclusion And Policy/management Options}

Abaya-Chamo lake-wetland supports the livelihood of people by providing multiple benefits such as provisions (e.g. fish, timber, firewood, water, fodder), supportive services for primary production (e.g. irrigation water, farmland, supply rainfall, balance hydrological cycle) and wildlife habitat, cultural services (e.g. recreation, tourism, aesthetic) and regulatory services (e.g. carbon sink, regulate air quality and climate, etc.). The lake-wetland is degraded due to farm expansion, sedimentation, use of the lakes' water for irrigation, invasive plant species (e.g. emboch), resource overuse ('tragedy of the commons scenario'), etc., which were rooted by rapid population growth, open access to the wetland resources, limited protection and lack of legal framework on the use and abuse of the wetland resources. The lakes' salty-water based irrigation is expected to result in chemical land degradation to the extent of abandoning crop farming in the next few decades unless some actions are taken. The eutrophication problem of Abaya and Chamo lakes resulting from human encroachment induced loss of the wetland's buffer zone, and increasing siltation and chemical pollution requires urgent response from stakeholders. This is so because, the invasive emboch-plant leads to dwindling aquatic resources (e.g. fish, crocs, etc.), loss of economic and tour benefits, and the change in local climate thereby dehydrating the lake-water, and depleting the dissolved $\mathrm{O}_{2}$ and $\mathrm{CO}_{2}$ storage capacity of the lakes rapidly.

To curb the problems of the lake-wetland, the government should: (i) formulate clear policy, institutional and legal framework on the management of wetlands; (ii) intervene physical and vegetative measures on the uplands surrounding Abaya-Chamo wetland; (iii) demarcate clear buffer zone so as to limit encroachment of people to the lake-wetland; and (iv) integrate wetland management objectives with other development goals.

\section{Abbreviations}

ETB: Ethiopia Birr

FGD: Focus group discussion

$\mathrm{HHH}$ : Household head

TLU: Total Livestock Unite

SPSS: Statistical Package for the Social science

\section{Declarations}

\section{Availability of data and materials}

All data generated or analyzed during this study are available upon request.

\section{Acknowledgements}


The authors wish to thank assistants of data collection for this study. We would also like to thank the reviewers of this article for their critical observations and everyone who contributed to the improvement of the paper. Finally, we gratefully acknowledge the financial support of the Arba Minch University.

\section{Authors' contributions}

TZ has major the overall activities of the research process such as designing the study, data collection, analysis, interpretation and writing the draft manuscript; VG, YK and AG have made significant contribution by providing constructive guidance, critical comments and suggestions in the manuscript preparation process as well as editing the manuscript. All authors read and approved the final manuscript.

\section{Funding}

The first author acknowledges Arba Minch University for financial support of this study.

\section{Ethics Declarations}

\section{Ethics approval and consent to participate}

An effort was made to conduct the research in an ethical manner. A research area permission letter was obtained from the concerned institutions and the participants' consent was asked before commencing the interviews, discussions and taking photographs.

\section{Competing interests}

The authors have declared that no competing interests exist.

\section{Consent for publication}

All authors agreed and approved the manuscript for publication in Sustainable Environment Research.

\section{Publisher's Note}

Springer Nature remains neutral with regard to jurisdictional claims in published maps and institutional affiliations.

\section{References}

1. Akwetaireho, S. and Getzner, M. (2010) Livelihood dependence on ecosystem services of local residents: a case study from Mabamba Bay wetlands (Lake Victoria, Uganda).International Journal of Biodiversity Science Ecosystem Services and Management, 6 (1-2),75-87.

2. Alemayehu, T., Ayenew, T., and Kebede, S., (2006). Hydrogeochemical and Lake Level Changes in the Ethiopian Rift. Journal, 316: 290 - 300 
3. Assefa, E., and Bork, H.R., (2016). Dynamics and Driving Forces of Agricultural Landscapes in Southern Ethiopia: a Case Study of Chencha and Arba Minch Areas. Journal of Land Use Science, 11 (3): 278 - 293, http://dx.doi.org/10.1080/1747423X.2014.940613

4. Ayenew, T., (2002). Recent Changes in the Level of Lake Abiyata, Central Main Ethiopian Rift. Hydrological Sciences-Journal-des Sciences Hydrologiques, 47: 493 - 503

5. Bakala, F., et al. (2019). Socioeconomic Importance of Wetlands in Southwestern Ethiopia: Evidences from Bench-Maji and Sheka Zones. J Ecol \& Nat Resour, 3 (3):

6. Bjerstedt, T.W. (2011). Impacting Factors and Cumulative Impacts by Midcentury on Wetlands in the Louisiana Coastal Area. Journal of Coastal Research, 27 (6): 1029 - 1051

7. Boyd, J., (2012). Economic Valuation, Ecosystem Services, and Conservation Strategy, in: C. Quest, M. Gordon and M. Betty (eds.), Measuring Nature's Balance Sheet of 2011 Ecosystem Services Seminar Series (pp. 177 - 189), Palo Alto: Gordon and Betty Moore Foundation; www.moore.org

8. CBD (Convention on Biological Diversity) (2015). Wetlands and Ecosystem Services: CBD Press Brief. World Wetlands Day, Ramsar Convention on Wetlands and the Secretariat of the Convention on Biological Diversity, Ramsar: CBD (Switzerland). www.cbd.int

9. Clarkson, B.R, Ausseil, A.E, and Gerbeaux, P. (2014). Wetland Ecosystem Services. ResearchGate, 191 - 202 https://www.researchgate.net/publication/260436894

10. Coomes, O.T., Barhamb B. L. and Takasakic Y. (2004). Targeting Conservation-Development Initiatives in Tropical Forests: Insights from Analyses of Rainforest Use and Economic Reliance among Amazonian Peasants. Ecological Economics, 51: 47 - 64

11. Creswell, J.W (2009). Research Design: Quantitative, Qualitative and Mixed Method Approaches. Third Edition, Los Angles: the SAGE Publications Ltd., USA

12. CSA (Central Statistical Authority) (2015). Arba-Minch Zuria (Woreda) Demographic Survey Surveillance and Aids Mortality Surveillance. Baseline Report. Addis Ababa: CSA, Ethiopia

13. Davidson, N. C. (2014). How Much Wetland Has the World Lost? Long-term and Recent Trends in Global Wetland Area. Marine and Freshwater Research, 65: 934 - 941

14. Dise, N.B. (2009). Peatland Response to Global Change. Science, 326: 810 - 811

15. Dixon, A. B., \& Wood, A. P. (2003). Wetland Cultivation and Hydrological Management in Eastern Africa: Matching Community and Hydrological Needs through Sustainable Wetland Use. Natural Resources Forum, 27, 117-129. https://doi.org/10.1111/1477-8947.00047

16. Egoh, B.N., O’Farrell, P.J., Charef, A., Gurney, L.J., Koellner, T., Abi, H.N., Egoh, M., and Willemen, L. (2012). An African Account of Ecosystem Service Provision: Use, Threats and Policy Options for Sustainable Livelihoods, Ecosystem Services, 2: 71 - 81

17. EMA (Ethiopian Mapping Agency) (1988). Topographic Map of Ethiopia with a Scale 1:50,000. Addis Ababa: EMA, Ethiopia

18. Engidawork, A. (2001). Soils, Soil Degradation and Land Use/Cover Pattern of Hare Watershed South Rift Valley of Ethiopia; Research Report Part I. Arba Minch: Arba Minch Water Technology Institute 
(Ethiopia)

19. Erwin, K.L. (2009). Wetlands and Global Climate Change: The Role of Wetland Restoration in a Changing World. Wetland Ecol. Management, 17(1): 71 - 84

20. Feoli, E and Zerihun, W. (2000). Fuzzy Set Analysis of the Ethiopian Rift Valley Vegetation in Relation to Anthropogenic Influences. Plant ecology, 147: 219 - 225

21. Fisher Charles R., Amanda W. J. Demopoulos, Erik E. Cordes, Iliana B. Baums, Helen K. White, Jill R. Bourque BioScience, Volume 64, Issue 9, September 2014, Pages 796-807, https://doi.org/ 10.1093/ biosci/biu129

22. Gautam, Y., Andersen, P. (2016). Rural livelihood diversification and household well-being: Insights from Humla, Nepal. Journal of Rural Studies, 44, 239-249.

23. Gelaw, A., (2007). Land Use Change and GIS-Based Land Suitability Analysis in Southern Rift Valley of Ethiopia: The Case of Lante Alluvial Fan. M.A Thesis, Addis Ababa: Addis Ababa University, Ethiopia

24. Gelaw, A., (2019). Analysis of the Values and Impacts of Ecosystem Services Dynamics, and Valuation of Selected Provisioning Services in Hare River Catchment, Southern Ethiopia. A PhD Dissertation, Addis Ababa: Addis Ababa University, Ethiopia

25. Gujarati, D., (2004). Basic Econometrics. $4^{\text {th }}$ Edition, McGraw-Hill: McGraw-Hill Companies Inc.,

26. Heathwaite, A.L., Jones, L., Paterson, J., Simpson, L., Thompson, A., and Turley, C (2012). The Drivers of Change in UK Ecosystems and Ecosystem Services. A Technical Report, London: National Ecosystem Assessment, UK

27. Kebede, Y., (2012). Land Use/Cover Dynamics, Environmental Degradation and Management Practices in Hare River Catchment, Abaya-Chamo Basin, Ethiopia, Using Geo-Spatial Technology, A Ph.D Thesis, Andhra: Department of Env'tal Sciences (Andhra University), India

28. JICA (Japan International Cooperation Agency) (2012). The Study on Groundwater Resources Assessment in the Rift Valley Lakes Basin in the Federal Democratic Republic of Ethiopia. Kokusai Kogyo Co., Ltd.: JICA and Ministry of Water and Energy, Ethiopia.

29. Lehner, B., and Döll, P., (2004). Development and Validation of a Global Database of Lakes, Reservoirs and Wetlands. Journal of Hydrol., 296 (1-4): 1 - 22

30. McCartney, Rebelo, LM., M.P. \& Finlayson, C.M. Wetlands of Sub-Saharan Africa: distribution and contribution of agriculture to livelihoods. Wetlands Ecol Manage 18, 557-572 (2010). https://doi.org/10.1007/s11273-009-9142-x

31. MEA (Millennium Ecosystem Assessment) (2005). Ecosystems and Human Well-being: Wetlands and Water Synthesis. Washington, DC: World Resources Institute, USA

32. MEA (Millennium Ecosystem Assessment) (2005a). Ecosystems and Human Well-Being: Synthesis; Washington DC: Island Press, Website: http://www.maweb.org

33. MEA (Millennium Ecosystem Assessment) (2005b). Ecosystems and Human Well-being: Current State and Trends, Volume 1, Washington D.C: Island Press, Website: http://www.maweb.org 
34. Moser, M., Prentice, C. and Frazier, S. (1996). A Global Overview of Wetland Loss and Degradation, Proceedings of Ramsar COP6 (Brisbane 1996), Vol. 10/12, Technical Session B at p. 21.

35. NMA (National Meteorological Agency) (2019). Climate (Temperature and Rainfall) Data Records within 1982 - 2018. A Report by the Meteorological Station at Arba Minch University (Abaya-Chamo Basin). Addis Ababa: the NMA (Ethiopia)

36. Rahman MM, Islam MA (2005) Better options for IFM: uptake promotion NRSP project R8306 final technical report: annex a. Center for Natural Resource Studies (CNRS), Dhaka

37. Ramsar Convention Secretariat, 2006. Wise use of wetlands: Concepts and approaches for the wise use of wetlands. 4th ed. Gland: Ramsar Convention Secretariat.

38. Reed, P. Rowcroft, S. Cade, S. Savege, A. Scott, J. Black, A. Brace, A.C. Evely, C. (2013) White Visitor Giving Payment for Ecosystem Service Pilot Final Report Defra, London

39. Sakané, N., Becker, M., Langensiepen, M. et al. Typology of Smallholder Production Systems in Small East-African Wetlands. Wetlands 33, 101-116 (2013). https://doi.org/10.1007/s13157-012-0355-z

40. Scoones, I. (2009).Livelihoods perspectives and rural development. The Journal of Peasant Studies, 36(1), 171-196.

41. Swinton, S., Lupi, F., Robertson, G., and Hamilton, S., (2007). Ecosystem Services and Agriculture: Cultivating Agricultural Ecosystems for Diverse Benefits; Ecological Economics, 64: 245 - 252

42. Symeonakis, E., Drake, N. 10-Daily soil erosion modelling over sub-Saharan Africa. Environ Monit Assess 161, 369-387 (2010). https://doi.org/10.1007/s10661-009-0754-7

43. TEEB (The Economics of Ecosystems and Biodiversity) (2013). The economics of ecosystems and biodiversity for water and wetlands. London and Brussels: Institute for European Environmental Policy (IEEP)

44. Teffera F.E, Lemmens P, Deriemaecker A, Brendonck L., Dondeyne S, Deckers J, Bauer, H. Gamo, F.W, De Meester, L.A (2017). Call to Action: Strong Long-term Limnological Changes in the Two Largest Ethiopian Rift Valley Lakes, Abaya-Chamo. Inland Waters, 7, 129 - 137

45. Tesfau, B., Brook L, and Seyoum M. (2018). Interaction of Local Community and Wetlands: The Case of Lake Ziway Shore Area, Ethiopia. International Journal of Scientific and Research Publicat, 8 (2): $420-425$

46. Trinh T.G., Hoang H. C. and Le Q.T. (2003). Wetlands Study: Lessons Learned and Future Challenges. In: Torell M., Salamanca A. M., Ratner B. D. (eds) Wetlands Management in Vietnam: Issues and Perspectives, pp. 71 - 73, Penang: World Fish Centre, Malaysia

47. Uncha, A., (2014). Indigenous Soil Management Techniques and the Impact of Modern Agricultural Technologies in Gamo Highlands, Southern Ethiopia; Ph. D Dissertation, Pretoria: University of South Africa

48. Van Asselen, P.H. Verburg, J. Vermaat, J.H. Janse (2013). Drivers of wetland conversions: a global meta-analysis. PLoS ONE, 8, pp. e81292, doi: http://dx.doi.org/10.1371/journal. pone.0081292 
49. Zedler, J.B. and Kercher, S. (2005). Wetland Resources: Status, Trends, Ecosystem Services and Restorability. Annual Review of Environment and Resources, 30: 39 - 74

50. Zhang, W., Ricketts, T., Kremen, C., Carney, K., and Swinton, S., (2007). Ecosystem Services and Disservices to Agriculture; Ecological Economics, 64: 253 - 260

51. Zinabu G., (2002). The Ethiopian Rift Valley Lakes: Major Threats and Strategies for Conservation; In: Tudorancea, C. and Taylor, W.D., (eds), Ethiopian Rift Valley Lakes, pp. 259 - 271, Leiden: Backhuys Publishers, Netherlands

\section{Figures}

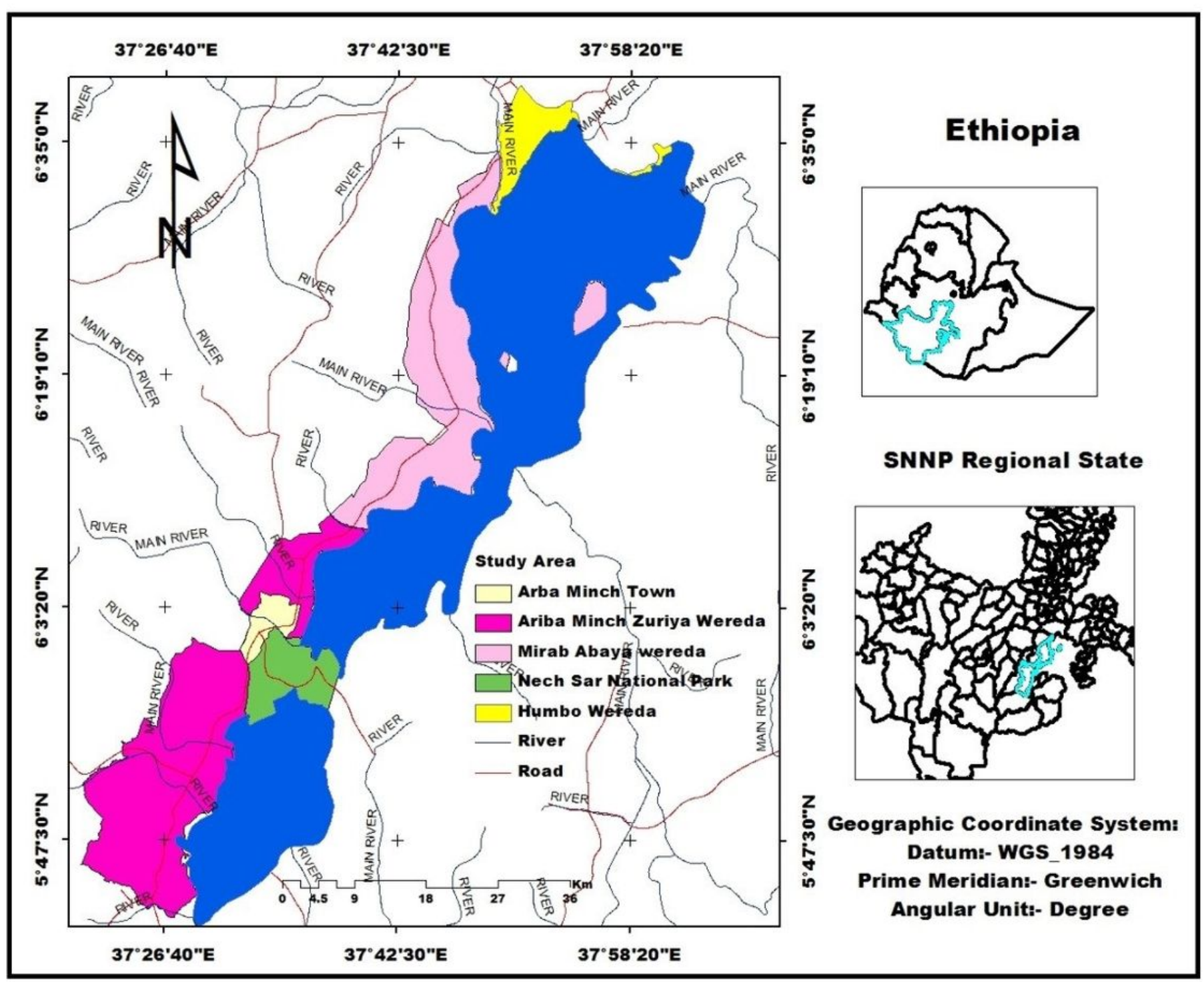

Figure 1 
Location of Study Area. Note: The designations employed and the presentation of the material on this map do not imply the expression of any opinion whatsoever on the part of Research Square concerning the legal status of any country, territory, city or area or of its authorities, or concerning the delimitation of its frontiers or boundaries. This map has been provided by the authors.

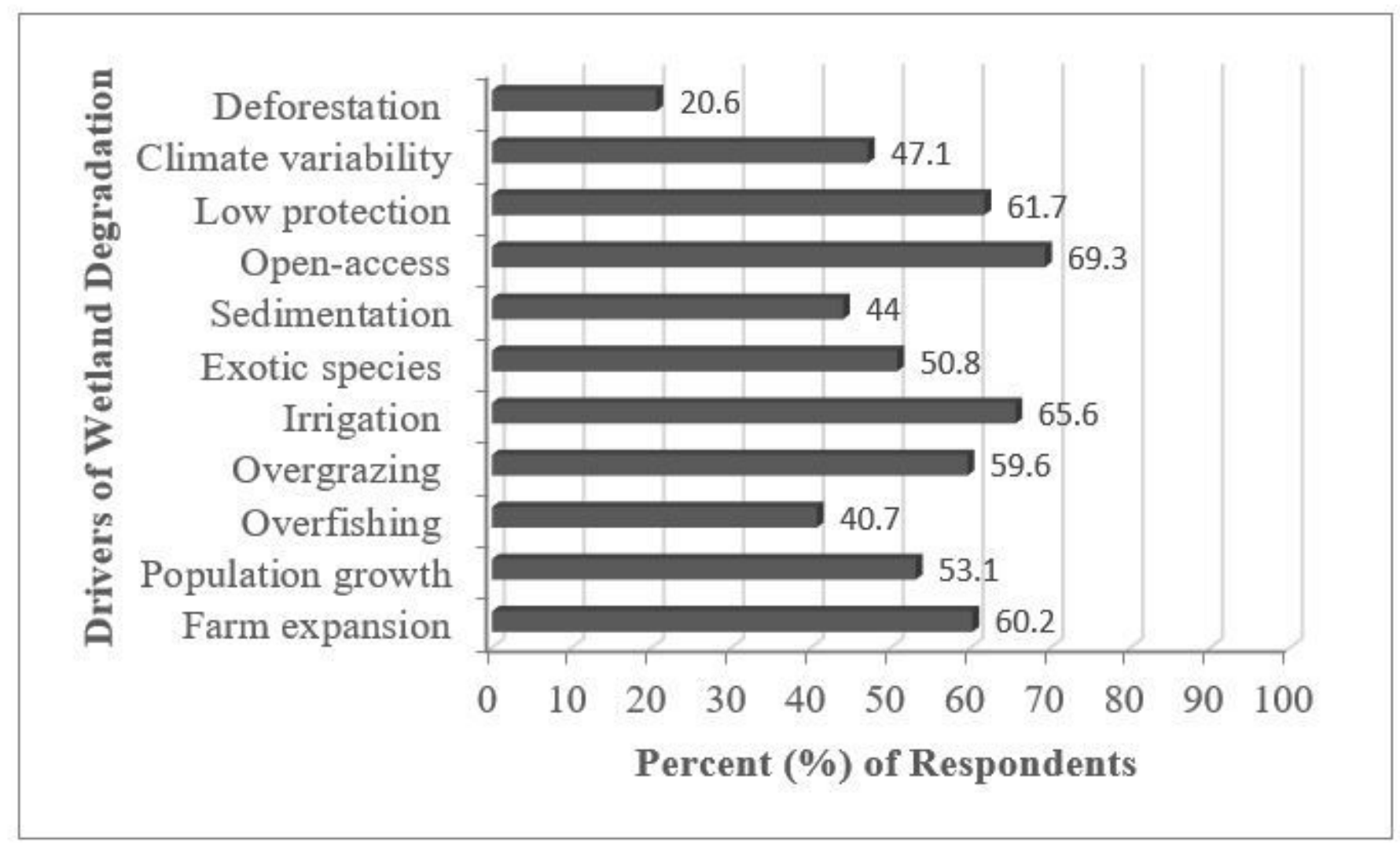

\section{Figure 2}

Major driving forces (causes) for the degradation/loss of Abaya-Chamo wetland based on proportion (\%) of respondents. Source: own design via excel, 2020. [Note: Figure 3.1 is designed using data gathered through multiple response-options] 